\title{
Findings About Laterality
}

National Cancer Institute

\section{Source}

National Cancer Institute. Findings About Laterality. NCI Thesaurus. Code C123974.

A qualifier for the side of the body the findings about test is performed. 